\title{
Modelling tax consciousness evaluation in the context of economic development uncertainty
}

\author{
H. Kucherova ${ }^{1}$, O. Pokataieva ${ }^{2}$, O. Bilska ${ }^{3}$ \\ ${ }^{I}$ Chair of Economics, Classic Private University, Zaporizhzhia, Ukraine \\ ${ }^{2}$ Chair of Accounts and Taxation, Classic Private University, Zaporizhzhia, Ukraine \\ ${ }^{3}$ Chair of Economic Theory, Marketing and International Economy, Classic Private University, Zaporizhzhia, Ukraine
}

\section{Article Info}

Received Jan 10, 2019

\section{Keyword:}

Analytic hierarchy process

Attitude

Awareness

Behavior

Controlling bodies

Government

Tax consciousness

Taxpayers

\begin{abstract}
The aim of this study is to compare a finite set of subjects of taxation by means of evaluating their relative importance by tax consciousness levels using a scale in T. Saaty's analytic hierarchy process. As a result, the highest value is obtained for large taxpayers, followed by the government, then controlling bodies, and the lowest value is obtained for small taxpayers. The values of the cognitive component for all subjects of taxation are high due to the high accessibility of education, lifelong learning, and development of advisory functions of controlling bodies. Middle-high values of emotional and volitional component are determined by the subjective nature of managerial decision-making and the degree of trust in government and taxation system. Low values of the behavioral component are determined by the subject's socio-economic role which affects the availability of tax behavior alternatives and their risks in a certain area of activity. It has been proved that there are no standard values for the structural elements and tax consciousness as a whole as they simultaneously represent the cause and effect of imbalances in the functioning and development of the socio-economic system of the country.
\end{abstract}

\section{Corresponding Author:}

First Author,

Chair of Economics,

Classic Private University,

70-b Zhukovsky, Zaporizhzhia 69002, Ukraine.

Email: kucherovahanna@gmail.com

\section{Introduction}

The multilevel and multipurpose system of tax management which is adopted in developed countries is aimed at reforming [7] in order to achieve administrative transparency [28], monitor compliance with law, address tax behavior consequences [32] and thus improve tax culture in general [25]. Taxation subjects' behavior is determined by the total of the decisions they make, while every of these decision is determined by various external environmental factors, such as trust in the authorities, rigidity of the taxation system, profitability, fairness of tax burden [6], [29] as well as internal factors, such as peculiarities of their current tax consciousness [26]. Differences in taxation subjects' behavior are also determined by the role (government, general public, controlling bodies, taxpayers, tax agents) [14] they perform in their socio-economic environment [33]. Based on the reflection of the perceived tax situation, individual tax consciousness forms an appropriate response, determines decision-making in terms of taxation, and therefore the type of tax behavior. Consequently, the type of tax behavior can be seen as a derivative of the tax consciousness level which is why governments and controlling bodies should focus on causes of tax behavior, determined by taxation subjects' tax consciousness, instead of its effects. Tax behavior is manifested externally, so it is subject to research, while the level and structure of tax consciousness are difficult to formalize and evaluate. At the heart of all attempts to evaluate tax consciousness there are methods of sociological, statistical research [1], [12], agentoriented simulation [11]. However, the results of these research methods are only relevant at the time of their 
publication, since they rely on the opinions of respondents whose opinion is versatile in the context of significant dynamics of socio-economic processes. An attempt to take into account the fuzziness of judgments while evaluating tax consciousness was made in a previous work [13], [15] using fuzzy logic methods (Mamdani algorithm). Since the level of tax consciousness becomes evident in the process of taxation, reflexive management methods proved effective as well [16], [17]. The available experience of applied research on tax consciousness, proving strength of certain cause-effect relationships provides basis for expert methods application including T. Saaty's [27], [30] analytic hierarchy process, which should be given special attention.

\section{Material and methods}

Tax consciousness is seen as a tool used to form a subjective image (both real and ideal) of taxation by means of reflecting input tax information through the prism of tax awareness, emotions and evaluations that determine specific perception of and attitude to taxation which results in revealing problems and providing guidelines on how to act in a particular tax situation [15]. From the point of view of the systems approach and the theory of psychology, tax consciousness is a finite aggregate of functional elements (cognitive, emotional and volitional, behavioral ones) with their properties, plurality of connections between them, aims and possibilities, which are studied independently and in the context of socio-economic environment at a stated period of time. Goals and opportunities are determined by taxation subjects' socio-economic role which affects the level of their tax consciousness. Thus, it is appropriate to evaluate tax consciousness and its components in the context of interaction between individual subjects of taxation when the properties of the cognitive, behavioral, emotional and volitional components become evident, which provides a platform to substantiate and compare their values. The aim of this study is to compare a finite set of subjects of taxation by means of evaluating their relative importance by tax consciousness levels using a scale in T. Saaty's analytic hierarchy process (Saaty, 1980). The method is based on the systems approach whose main elements are expert perspective of problem solving and results of cause-effect relationships analysis.

We shall consider $\frac{n(n-1)}{2}$ equations, where $n$ is the number of criteria at one level. Using the equations results, we create a pairwise comparison matrix $A=\left\|a_{i j}\right\|_{m \times m}$. Consistency between results, i. e. $a_{i j}=w_{i} / w_{j}$, for $i, j=\overline{1, m}$ can be explained as follows $a_{i j}=1, a_{i j}=1 / a_{i j}$ for $i, j=\overline{1, m}$, as $x^{i}$ has $a>1$ times more weight relative to $x^{j}$. If it is perfectly consistent, $A=\left(\begin{array}{c}w_{1} \\ \ldots \\ w_{m}\end{array}\right)=m\left(\begin{array}{c}w_{1} \\ \ldots \\ w_{m}\end{array}\right)$ as relative weight vector $\left(w_{1}, \ldots, w_{m}\right)^{T}$ is the eigenvector of matrix $A$, and corresponds to the eigenvalue $A, \lambda=\mathrm{m}$ [24]. Thus, we can calculate relative priorities $\lambda_{\max } \rightarrow m, m$ - eigenvalue of matrix $\mathrm{A}$, and minimum distance between $\lambda$ and $m$ means better consistency of judgments [25]. Then relative priority vector $\left(w_{1, \ldots}, w_{m}\right)^{T}$ is built using the geometric mean formula. In particular, relative weight values for every row of matrix $A$ are calculated as follows: $w_{i}=\frac{\sqrt[m]{a_{1 i}, \ldots, a_{i m}}}{\sum_{i=1}^{m} \sqrt{a_{1 i}, \ldots, a_{i m}}}, i=\overline{1, m}$. With results for $w_{i}$, the eigenvalue of matrix $A$ is calculated by determining $A \times w$ [27]. After evaluating $\lambda_{\max }$ the consistency index is obtained: $J_{p}=\frac{\lambda_{\max }-m}{m-1}$. The results are compared to the standard ones of $J_{e}$. If $J_{e} \leq 0,1 \times J_{e}$, evaluation results satisfy the research conditions [27].

Table $1:$ Standard consistency values

\begin{tabular}{|l|c|c|c|c|c|c|c|c|c|c|c|c|c|}
\hline $\begin{array}{l}\text { Number } \\
\text { of objects }\end{array}$ & 3 & 4 & 5 & 6 & 7 & 8 & 9 & 10 & 11 & 12 & 13 & 14 & 15 \\
\hline J e & 0.58 & 0.9 & 1.12 & 1.24 & 1.32 & 1.41 & 1.45 & 1.49 & 1.51 & 1.54 & 1.56 & 1.57 & 1.59 \\
\hline
\end{tabular}

Global priorities for the elements of a certain level are evaluated on the principle of synthesis, namely calculating the sum of the product of the local priorities for each element of a certain hierarchy level $w_{i}^{*}$ and global priorities of the previous level elements $K_{i}$ :

$$
M_{i}=\sum_{i, j=1}^{m} w_{i}^{*} \times K_{i} .
$$

At the second stage of the study, the factors of the second level of the hierarchy are given priorities and 
arranged according to the decrease of their weight. The work [11] proves that compliance with tax regulations and attitude to taxation are interrelated and enhance each other. Improving the attitude to taxation was found [15] to raise the level of tax consciousness by $35 \%$, increase the level of tax awareness by $34 \%$ and make tax behavior 32\% more active. Thus, the factors are arranged by their weight in descending order which allows us to calculate each one's weight using the first $S$. Fishburn's formula. Since $E \geq K \geq P, m=3$, factors' wights form a descending arithmetic progression, and therefore are calculated as follows:

$$
W_{I}=\frac{2(m-i+1)}{m(m+1)}, i=\overline{1, m} . W_{E}=0,5 ; W_{K}=0,33 ; W_{P}=0,17 .
$$

With regard to the systemic structure of tax consciousness, its elements on every level of the hierarchy are subject to evaluation (Fig. 1).

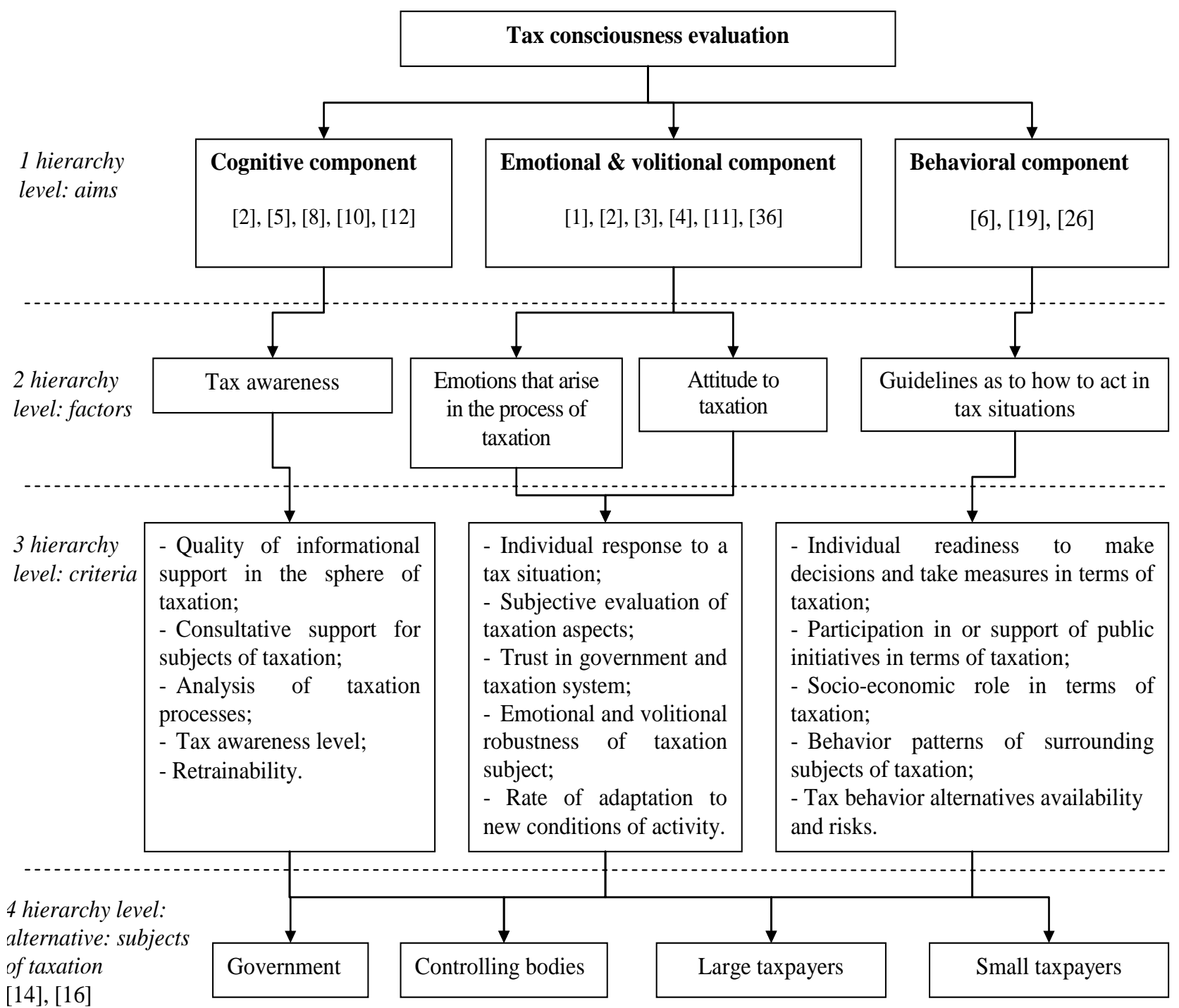

Figure 1. Hierarchical model of evaluating the level of tax consciousness of taxation subjects

The first level of the hierarchy represents the objectives of evaluating the components of tax consciousness: cognitive $K$, emotional-volitional $E$, and behavioral $P$ ones. The second level includes factors determining the previous level components, namely: tax awareness, emotions that arise in the process of taxation, attitude to taxation, guidelines on how to act in terms of taxation. The third level of the hierarchy gives criteria for every factor which specify the purpose of the study. At the fourth level of the hierarchy, there are four alternatives (government, controlling bodies, large and small taxpayers) that are evaluated according to the criteria of the first level. At the third stage of the study, the criteria of the third level of the hierarchy are analyzed against the 
second level elements. At the fourth stage, we get the global priorities for the third level elements based on the principle of synthesis. At the fifth stage we identify local priorities for the fourth level elements in relation to the third level criteria. The proposed approach to tax consciousness evaluation allows, based on identified cause and effect relationships, for a quantitative evaluation of its level and comparing the values by subjects of taxation.

\section{Results}

The criteria of the third level of the hierarchy are analyzed against the second level elements. For this purpose, a matrix of pair-wise comparisons was designed (Table 2).

The eigenvector of local priorities:

Priority vector, : $\overline{d_{i}}$ :

$$
\begin{aligned}
& \overline{d_{1}}=\sqrt[5]{1 \times 1 \times 2 \times 0,20 \times 0,20}=0,60 ; \overline{d_{2}}=\sqrt[5]{1 \times 1 \times 1 \times 0,14 \times 0,4}=0,46 \\
& \overline{d_{3}}=\sqrt[5]{0,5 \times 1 \times 1 \times 0,5 \times 0,33}=0,61 ; \overline{d_{4}}=\sqrt[5]{5 \times 7 \times 2 \times 1 \times 0,33}=01,88 \\
& \overline{d_{5}}=\sqrt[5]{5 \times 7 \times 3 \times 3 \times 1}=3,16 . \quad \sum_{i=1}^{n} \overline{d_{i}}=0,60+0,46+0,61+1,88+3,16=6,71
\end{aligned}
$$

\begin{tabular}{|c|c|c|c|c|c|c|c|}
\hline \multirow{2}{*}{$\begin{array}{l}\text { Line numbers and names of } \\
\text { compared elements }\end{array}$} & \multicolumn{5}{|c|}{$\begin{array}{c}\text { Numbers } \\
\text { of compared elements }\end{array}$} & \multirow{2}{*}{$\begin{array}{l}\text { Priority vector, } \\
\qquad \bar{d}_{\iota}\end{array}$} & \multirow{2}{*}{$\begin{array}{l}\text { Local } \\
\text { priorities, } d\end{array}$} \\
\hline & 1 & 2 & 3 & 4 & 5 & & \\
\hline $\begin{array}{l}\text { 1. Quality of informational } \\
\text { support }\end{array}$ & 1 & 1 & 2 & 0.20 & 0.20 & 0.60 & 0.09 \\
\hline $\begin{array}{l}\text { 2. Consultative support for } \\
\text { subjects of taxation }\end{array}$ & 1 & 1 & 1 & 0.14 & 0.14 & 0.46 & 0.07 \\
\hline $\begin{array}{l}\text { 3. Analysis of taxation } \\
\text { processes }\end{array}$ & 0.50 & 1 & 1 & 0.50 & 0.33 & 0.61 & 0.09 \\
\hline 4. Tax awareness level & 5 & 7 & 2 & 1 & 0.33 & 1.88 & 0.28 \\
\hline 5. Retrainability & 5 & 7 & 3 & 3 & 1 & 3.16 & 0.47 \\
\hline Row-vector (sum) & $\mathbf{1 2 . 5}$ & 17 & 9.0 & 4.84 & 2.01 & 6.71 & 1.00 \\
\hline Consistency evaluation & & & & $=5.4$ & $I_{C}$ & $.101, I_{C R}=0.09$ & \\
\hline
\end{tabular}

Table 2 : Matrix of pairwise comparisons by "Cognitive component" factor

Local priorities, $d_{i}$ :

$d_{1}=\frac{0,6}{6,71}=0,09 ; \quad d_{2}=\frac{0,46}{6,71}=0,07 ; \quad d_{3}=\frac{0,61}{6,71}=0,09 ;$

$d_{4}=\frac{1,88}{6,71}=0,28 ; \quad d_{5}=\frac{3,16}{6,71}=0,47 ; \quad \sum_{i=1}^{n} d i=0,09+0,07+0,09+0,28+0,47=1$.

Now we can calculate the value for the consistency of judgments.

We find the maximum eigenvalue $\lambda_{\max }$ for the matrix of pair-wise comparisons. We calculate the $s_{i}$ row-vector for every column of the matrix of pair-wise comparisons:

$S_{1}=\sum_{i, j=1}^{5} 1+1+0,5+5+5=12,50 ; S_{2}=\sum_{i, j=1}^{5} 1+1+1+7+7=17$

$S_{3}=\sum_{i, j=1}^{5} 2+1+1+2+3=9 ; S_{4}=\sum_{i, j=1}^{5} 0,2+0,14+0,5+1+3=4,84$;

$\lambda_{\max }=\sum_{i=1}^{5} 0,09 \times 12,5+0,07 \times 17+0,09 \times 9+0,28 \times 4,84+0,47 \times 2,01=5,406$.

Now we can find the index and the ratio of the consistency of expert judgments. The index of consistency $\left(I_{C}\right)$ is calculated as follows : $J_{C}=\frac{5,406-5}{5-1}=0,101$. We can compare the obtained index value to the standard one (Table 1). $I_{C} \leq 0,1 \times I_{S}$. Since the $I_{C}=\frac{0,101}{1,12}=0,09$ condition is fulfilled, we can conclude that the results we have arrived at are trustworthy. The consistency ratio is $9 \%$ of the standard value. We have obtained trustworthy results since the ratio is under $10 \%$. 
We can do calculations for the "Emotional and volitional" and "Behavioral" components likewise and write the results obtained into Tables 3,4. These results are satisfactory and trustworthy, because the consistency ratio does not exceed the critical value of $10 \%$.

Table 3: Matrix of pairwise comparisons by "Emotional and volitional component" factor

\begin{tabular}{|c|c|c|c|c|c|c|c|}
\hline \multirow{2}{*}{$\begin{array}{l}\text { Line numbers and names of } \\
\text { compared elements }\end{array}$} & \multicolumn{5}{|c|}{$\begin{array}{c}\text { Numbers } \\
\text { of compared elements }\end{array}$} & \multirow{2}{*}{$\begin{array}{l}\text { Priority } \\
\text { vector, } \\
\bar{d}_{l}\end{array}$} & \multirow{2}{*}{$\begin{array}{l}\text { Local } \\
\text { priorities, } \mathrm{d}_{\mathrm{i}}\end{array}$} \\
\hline & 1 & 2 & 3 & 4 & 5 & & \\
\hline $\begin{array}{l}\text { 1. Individual response to tax } \\
\text { situation }\end{array}$ & 1 & 1 & 0.20 & 0.20 & 1 & 0.53 & 0.09 \\
\hline $\begin{array}{l}\text { 2. Subjective evaluation of taxation } \\
\text { aspects }\end{array}$ & 1 & 1 & 3 & 1 & 3 & 1.55 & 0.28 \\
\hline $\begin{array}{l}\text { 3. Trust in government and taxation } \\
\text { system }\end{array}$ & 5 & 0.33 & 1 & 5 & 3 & 1.90 & 0.34 \\
\hline $\begin{array}{l}\text { 4. Emotional and volitional } \\
\text { robustness of taxation subject }\end{array}$ & 5 & 1 & 0.20 & 1 & 1 & 1.00 & 0.18 \\
\hline $\begin{array}{l}\text { 5. Rate of adaptation to new } \\
\text { conditions of activity }\end{array}$ & 1 & 0.33 & 0.33 & 1 & 1 & 0.64 & 0.11 \\
\hline Row-vector (sum) & 13 & 3.67 & 4.73 & 8.20 & 9.00 & 5.63 & 1.00 \\
\hline Consistency evaluation & & & $\lambda_{\mathrm{ma}}$ & 0.62 & $I_{C}=$ & $C R=0.0$ & \\
\hline
\end{tabular}

Table 4: Matrix of pairwise comparisons by "Behavioral component" factor

\begin{tabular}{|c|c|c|c|c|c|c|c|}
\hline \multirow{2}{*}{$\begin{array}{l}\text { Line numbers and names of } \\
\text { compared elements }\end{array}$} & \multicolumn{5}{|c|}{$\begin{array}{c}\text { Numbers } \\
\text { of compared elements }\end{array}$} & \multirow{2}{*}{$\begin{array}{l}\text { Priority vector, } \\
\qquad \bar{d}_{\iota}\end{array}$} & \multirow{2}{*}{$\begin{array}{l}\text { Local } \\
\text { priorities, } \mathrm{d}_{\mathrm{i}}\end{array}$} \\
\hline & 1 & 2 & 3 & 4 & 5 & & \\
\hline $\begin{array}{l}\text { 1. Individual readiness to make } \\
\text { decisions and take measures in } \\
\text { terms of taxation }\end{array}$ & 1 & 3 & 0.20 & 0.20 & 0.20 & 0.47 & 0.07 \\
\hline $\begin{array}{l}\text { 2. Participation in or support of } \\
\text { public initiatives in terms of } \\
\text { taxation }\end{array}$ & 0.33 & 1 & 0.20 & 0.20 & 0.20 & 0.31 & 0.05 \\
\hline $\begin{array}{l}\text { 3. Socio-economic role in terms } \\
\text { of taxation }\end{array}$ & 5 & 5 & 1 & 3 & 1 & 2.37 & 0.36 \\
\hline $\begin{array}{l}\text { 4. Behavior patterns of } \\
\text { surrounding subjects of taxation }\end{array}$ & 5 & 5 & 0.33 & 1 & 1 & 1.53 & 0.23 \\
\hline $\begin{array}{l}\text { 5. Tax behavior alternatives } \\
\text { availability and risks }\end{array}$ & 5 & 5 & 1 & 1 & 1 & 1.90 & 0.29 \\
\hline Row-vector (sum) & 16.33 & 19 & 2.73 & 5.40 & 3.40 & 6.58 & 1.00 \\
\hline Consistency evaluation & \multicolumn{7}{|c|}{$\lambda_{\max }=5.28, I_{C}=0.07, I_{C R}=0.062$} \\
\hline
\end{tabular}

At the fourth stage, we get the global priorities for the third level elements based on the principle of synthesis, the calculation results are shown in Table 5.

Table 5: Global priorities for the third level elements

\begin{tabular}{|c|c|c|}
\hline $\begin{array}{c}\text { Cognitive component: } \\
W_{1}=0.5\end{array}$ & $\begin{array}{c}\text { Emotional and volitional component } \\
W_{2}=0.33\end{array}$ & $\begin{array}{c}\text { Behavioral component } \\
W_{2}=0.17\end{array}$ \\
\hline $\mathrm{K}_{1}=0,5 \times 0,09=0,04$ & $\mathrm{~K}_{6}=0,33 \times 0,09=0,03$ & $\mathrm{~K}_{11}=0,17 \times 0,07=0,01$ \\
\hline $\mathrm{K}_{2}=0,5 \times 0,07=0,03$ & $\mathrm{~K}_{7}=0,33 \times 0,28=0,09$ & $\mathrm{~K}_{11}=0,17 \times 0,07=0,01$ \\
\hline $\mathrm{K}_{3}=0,5 \times 0,09=0,05$ & $\mathrm{~K}_{8}=0,33 \times 0,34=0,11$ & $\mathrm{~K}_{12}=0,17 \times 0,36=0,06$ \\
\hline $\mathrm{K}_{4}=0,5 \times 0,20=0,14$ & $\mathrm{~K}_{9}=0,33 \times 0,18=0,06$ & $\mathrm{~K}_{12}=0,17 \times 0,23=0,04$ \\
\hline $\mathrm{K}_{5}=0,5 \times 0,47=0,24$ & $\mathrm{~K}_{10}=0,33 \times 0,11=0,04$ & $\mathrm{~K}_{13}=0,17 \times 0,29=0,05$ \\
\hline
\end{tabular}

Thus, based on Table 6, we can conclude that the most important criteria of the third level are retrainability, trust in the government and taxation system, socio-economic role in terms of taxation. 
At the fifth stage we identify local priorities for the fourth level elements in relation to the third level criteria (see appendices: Tabular Hierarchy 7-21). Thorough analysis of the results obtained on the basis of the calculated consistency of judgments allows us to conclude that these results are satisfactory and trustworthy. For the obtained consistency indices, the $I_{C} \leq 0,1 \times I_{S}$ condition is fulfilled and the consistency ratio does not exceed the critical value of $10 \%$. At the last, sixth stage of the study, we obtain the global priorities of the fourth level elements, Table 6 . Based on the research done we can conclude that the level of tax consciousness is 0.271 for large taxpayers, 0.269 for the government, 0.240 for controlling bodies, and 0.220 for small taxpayers.

Table 6: Results of evaluating the level of tax consciousness of taxation subjects

\begin{tabular}{|l|c|c|c|c|}
\hline \multirow{2}{*}{ Subject of taxation } & \multicolumn{4}{|c|}{ Values } \\
\cline { 2 - 5 } & $\begin{array}{c}\text { Tax } \\
\text { consciousness }\end{array}$ & $\begin{array}{c}\text { Cognitive } \\
\text { component }\end{array}$ & $\begin{array}{c}\text { Emotional and } \\
\text { volitional component }\end{array}$ & $\begin{array}{c}\text { Behavioral } \\
\text { component }\end{array}$ \\
\hline Government & 0.269 & 0.132 & 0.097 & 0.040 \\
\hline Controlling bodies & 0.240 & 0.135 & 0.075 & 0.030 \\
\hline Large taxpayers & 0.271 & 0.173 & 0.059 & 0.039 \\
\hline Small taxpayers & 0.220 & 0.060 & 0.099 & 0.060 \\
\hline
\end{tabular}

The value of an index depends on the values of its components. It has been found that the highest influence of the cognitive component is observed for large taxpayers while the lowest is for small ones. The emotional and volitional component has been found to have significant influence for small taxpayers and less influence for large ones. The highest influence of the behavioral component on the level of tax consciousness is identified for small taxpayers while it is the lowest for controlling bodies.

The value of the cognitive component [2], [5], [10], [35] for all subjects of taxation is high due to the high accessibility of education, spread of lifelong learning ideas, development of advisory functions of controlling bodies, all of which had a general positive effect on the level of tax awareness. The emotional and volitional component is defined by trust in government and taxation system, and subjective nature of managerial decisions made. Values of the behavioral component are determined by the subject's socio-economic role which affects availability of tax behavior alternatives and their risks in a certain area of activities. The values obtained correspond to reality since it is large taxpayers who provide the bulk of tax revenues, have the required staff of tax professionals and enough capital to be initiators in the process of tax reforms, so their commercial interests take into account government bodies. Large taxpayers require special tax attention which has resulted in introducing specified offices for large taxpayers in the structure of fiscal services.

In addition to the study conducted on taxation subjects' tax consciousness, it is also defined as either a form of behavior, or emotions that arise in the process of taxation [23], [36], which, in our opinion, is one-sided. Tax consciousness is evaluated as a factor of fulfilling the tax duty conscientiously [23], or as a result of fulfilling the tax duty [15]. The paper [16], [17] substantiates the model of taxation subjects' tax consciousness on the principles of reflexive interaction and integral estimation, which results in a strategy of raising tax consciousness level. Tax consciousness evaluation tools are represented by the methods of sociological research (questionnaires) whose results are statistically estimated [10],[15], [18], [24], analyzed to identify cause and effect relationships and regularities using the correlation and regression analysis [4], [20], [22], Evolutionary Game Theory [19]. Fuzzy simulation scenarios [14] were developed and analyzed establishing paramount importance of forming positive attitude towards taxation in order to raise the level of tax consciousness. The work [1] grounds significance and positive influence of correlation between knowing tax regulations and responsible payment of tax liability. In addition, [8] point out that the aggregate of such factors as understanding taxes, awareness of tax payments, quality of revenue services, tax penalties has positive effect on conscious and conscientious compliance with tax regulations. Conscientious payment of tax liability in [6], [8] is achieved through ensuring positive attitude, high level of awareness, and solvency of taxpayers. [14] studied differences in forming tax consciousness of tax agents as compared to taxpayers in terms of their attitude to admitting tax duty. Using questionnaires, the researcher provides evidence that there is a significant difference in how subjects of taxation admit tax duty depending on the level of their tax consciousness. [14] notes that factors which stimulate the development of conscious tax payment on the part of tax agents and taxpayers include ensuring democracy and justice which can be achieved through changes in attitude to tax duty. Importance of understanding for fulfilling tax duty is justified in the study [3] where 
realization, understanding and readiness are argued to be the agents of forming positive attitude to taxation. In order to raise the level of tax consciousness it is recommended to focus on the differences in tax behavior of various subjects of taxation, build up trust in government structures and individual readiness to make decisions or take actions in terms of taxation, monitor the level of tax awareness in order to prevent it from being used for tax evasion, build positive attitude to taxation, achieve fairness of tax burden and responsibility of taxation subjects.

\section{Conclusions}

The study focuses on modeling evaluation of taxation subjects' tax consciousness using T. Saaty's analytic hierarchy process. It offers an insight into the content of tax consciousness and its structural elements which include cognitive, emotional and volitional, behavioral components. The paper presents a hierarchy of forming evaluations of tax consciousness of the government, controlling bodies, large and small taxpayers. The tax consciousness hierarchy is based on priority of emotions and attitude to taxation. Medium taxpayers and tax agents were deliberately excluded from the study as their functions partially coincide with the ones of other subjects of taxation under study. It has been proved that the most important criteria that determine tax consciousness are retrainability, trust in the government and taxation system, socio-economic role in terms of taxation. Based on the modeling results, it has been found that the level of tax consciousness is 0.271 for large taxpayers, 0.269 for the government, 0.240 for controlling bodies, and 0.220 for small taxpayers. With all subjects of taxation, high values are obtained for the cognitive component, medium values for the emotional and volitional component, and the lowest values are obtained for the behavioral one. In general, there are no standard values provided for tax consciousness and its components as its level is determined by a wide and multi-aspect range of factors, and moreover, time, place and method applied to study these factors also influence the results. The results of the study provide grounds to substantiate an optimal mix of tax consciousness structural components to maximize its level.

\section{Appendices}

\section{TABULAR HIERARCHY}

Table 7 : Local priorities of the fourth level elements by "Quality of informational support" criterion

\begin{tabular}{|c|c|c|c|c|c|c|}
\hline \multirow{2}{*}{$\begin{array}{l}\text { Line numbers and names of } \\
\text { compared elements }\end{array}$} & \multicolumn{4}{|c|}{$\begin{array}{c}\text { Numbers } \\
\text { of compared elements }\end{array}$} & \multirow{2}{*}{$\begin{array}{c}\text { Priority vector, } \\
\bar{u}_{\iota}\end{array}$} & \multirow{2}{*}{$\begin{array}{c}\text { Local } \\
\text { priorities, } \mathrm{u}\end{array}$} \\
\hline & 1 & 2 & 3 & 4 & & \\
\hline 1. Government & 1 & 2 & 5 & 7 & 2.89 & 0.50 \\
\hline 2. Controlling bodies & 0.50 & 1 & 5 & 7 & 2.05 & 0.35 \\
\hline 3. Large taxpayers & 0.20 & 0.20 & 1 & 3 & 0.59 & 0.10 \\
\hline 4. Small taxpayers & 0.14 & 0.14 & 0.33 & 1 & 0.29 & 0.05 \\
\hline Row-vector (sum) & 1.84 & 3.34 & 11.33 & 18.00 & 5.81 & 1.00 \\
\hline Consistency evaluation & & & $u_{\max }=4$. & $3, I_{C}=$ & $0.043, I_{C R}=0.047$ & \\
\hline
\end{tabular}

Table 8 : Local priorities of the fourth level elements by "Consultative support for subjects of taxation" criterion

\begin{tabular}{|c|c|c|c|c|c|c|}
\hline \\
\hline \multirow{2}{*}{$\begin{array}{c}\text { Line numbers and names of } \\
\text { compared elements }\end{array}$} & \multicolumn{4}{|c|}{$\begin{array}{c}\text { Numbers } \\
\text { of compared elements }\end{array}$} & \multirow{2}{*}{$\begin{array}{l}\text { Priority vector, } \\
\qquad \overline{u_{\imath}}\end{array}$} & \multirow{2}{*}{$\begin{array}{c}\text { Local } \\
\text { priorities, } \mathrm{u}_{\mathrm{i}}\end{array}$} \\
\hline & 1 & 2 & 3 & 4 & & \\
\hline 1. Government & 1.00 & 2.00 & 7.00 & 9.00 & 3.35 & 0.57 \\
\hline 2. Controlling bodies & 0.50 & 1.00 & 3.00 & 5.00 & 1.65 & 0.28 \\
\hline 3. Large taxpayers & 0.14 & 0.33 & 1.00 & 3.00 & 0.61 & 0.10 \\
\hline 4. Small taxpayers & 0.11 & 0.20 & 0.33 & 1 & 0.29 & 0.05 \\
\hline Row-vector (sum) & 1.75 & 3.53 & 11.33 & 18.00 & 5.91 & 1.00 \\
\hline Consistency evaluation & \multicolumn{6}{|c|}{$\lambda_{\max }=4.05, I_{C}=0.018, I_{C R}=0.019$} \\
\hline
\end{tabular}


Table 9: Local priorities of the fourth level elements by "Analysis of taxation processes" criterion

\begin{tabular}{|c|c|c|c|c|c|c|}
\hline \multirow{2}{*}{$\begin{array}{l}\text { Line numbers and names of } \\
\text { compared elements }\end{array}$} & \multicolumn{4}{|c|}{$\begin{array}{c}\text { Numbers } \\
\text { of compared elements }\end{array}$} & \multirow{2}{*}{$\begin{array}{c}\text { Priority vector, } \\
\qquad \bar{u}_{\imath}\end{array}$} & \multirow{2}{*}{$\begin{array}{c}\text { Local } \\
\text { priorities, u }\end{array}$} \\
\hline & 1 & 2 & 3 & 4 & & \\
\hline 1. Government & 1.00 & 1.00 & 5.00 & 9.00 & 2.59 & 0.45 \\
\hline 2. Controlling bodies & 1.00 & 1.00 & 3.00 & 7.00 & 2.14 & 0.37 \\
\hline 3. Large taxpayers & 0.20 & 0.33 & 1.00 & 5.00 & 0.76 & 0.13 \\
\hline 4. Small taxpayers & 0.11 & 0.14 & 0.20 & 1 & 0.24 & 0.04 \\
\hline Row-vector (sum) & 2.31 & 2.48 & 9.20 & 22.00 & 5.73 & 1.00 \\
\hline Consistency evaluation & \multicolumn{6}{|c|}{$\lambda_{\max }=4.10, I_{C}=0.034, I_{C R}=0.037$} \\
\hline
\end{tabular}

Table 10: Local priorities of the fourth level elements by "Tax awareness level" criterion

\begin{tabular}{|c|c|c|c|c|c|c|}
\hline \multirow{2}{*}{$\begin{array}{c}\text { Line numbers and names of } \\
\text { compared elements }\end{array}$} & \multicolumn{4}{|c|}{$\begin{array}{c}\text { Numbers } \\
\text { of compared elements }\end{array}$} & \multirow{2}{*}{$\begin{array}{c}\text { Priority vector, } \\
\bar{u}_{\imath}\end{array}$} & $\begin{array}{c}\text { Local } \\
\text { priorities, } \mathrm{u}_{\mathrm{i}}\end{array}$ \\
\cline { 2 - 6 } & 1 & 2 & 3 & 4 & 1.97 & 0.37 \\
\hline 1. Government & 1.00 & 1.00 & 5.00 & 3.00 & 2.43 & 0.46 \\
\hline 2. Controlling bodies & 1.00 & 1.00 & 5.00 & 7.00 & 2.00 & 0.11 \\
\hline 3. Large taxpayers & 0.20 & 0.20 & 1.00 & 3.00 & 0.59 & 0.07 \\
\hline 4. Small taxpayers & 0.33 & 0.14 & 0.33 & 1 & 0.35 & 1.00 \\
\hline Row-vector (sum) & $\mathbf{2 . 5 3}$ & $\mathbf{2 . 3 4}$ & $\mathbf{1 1 . 3 3}$ & $\mathbf{1 4 . 0 0}$ & $\mathbf{5 . 3 4}$ & \\
\hline Consistency evaluation & \multicolumn{7}{|c|}{$\lambda_{\max }=4.18, I_{C}=0.059, I_{C R}=0.065$} & \\
\hline
\end{tabular}

Table 11: Local priorities of the fourth level elements by "Retrainability" criterion

\begin{tabular}{|c|c|c|c|c|c|c|}
\hline \multirow{2}{*}{$\begin{array}{l}\text { Line numbers and names of } \\
\text { compared elements }\end{array}$} & \multicolumn{4}{|c|}{$\begin{array}{c}\text { Numbers } \\
\text { of compared elements }\end{array}$} & \multirow{2}{*}{$\begin{array}{l}\text { Priority vector, } \\
\qquad \overline{u_{\imath}}\end{array}$} & \multirow{2}{*}{$\begin{array}{c}\text { Local } \\
\text { priorities, } \mathrm{u}_{\mathrm{i}}\end{array}$} \\
\hline & 1 & 2 & 3 & 4 & & \\
\hline 1. Government & 1.00 & 0.50 & 0.20 & 0.33 & 0.43 & 0.08 \\
\hline 2. Controlling bodies & 2.00 & 1.00 & 0.20 & 0.50 & 0.67 & 0.12 \\
\hline 3. Large taxpayers & 5.00 & 5.00 & 1.00 & 5.00 & 3.34 & 0.61 \\
\hline 4. Small taxpayers & 3.00 & 2.00 & 0.20 & 1 & 1.05 & 0.19 \\
\hline Row-vector (sum) & 11.00 & 8.50 & 1.60 & 6.83 & 5.49 & 1.00 \\
\hline Consistency evaluation & & & 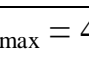 & & $I-$ & \\
\hline
\end{tabular}

Table 12: Local priorities of the fourth level elements by "Individual response to tax situation" criterion

\begin{tabular}{|c|c|c|c|c|c|c|}
\hline \multirow{2}{*}{$\begin{array}{l}\text { Line numbers and names of } \\
\text { compared elements }\end{array}$} & \multicolumn{4}{|c|}{$\begin{array}{c}\text { Numbers } \\
\text { of compared elements }\end{array}$} & \multirow{2}{*}{$\begin{array}{c}\text { Priority vector, } \\
\qquad \bar{u}_{\iota}\end{array}$} & \multirow{2}{*}{$\begin{array}{c}\text { Local } \\
\text { priorities, } \mathrm{u}\end{array}$} \\
\hline & 1 & 2 & 3 & 4 & & \\
\hline 1. Government & 1.00 & 1.00 & 0.33 & 0.20 & 0.51 & 0.10 \\
\hline 2. Controlling bodies & 1.00 & 1.00 & 0.33 & 0.25 & 0.54 & 0.10 \\
\hline 3. Large taxpayers & 3.00 & 3.00 & 1.00 & 0.33 & 1.32 & 0.26 \\
\hline 4. Small taxpayers & 5.00 & 4.00 & 3.00 & 1 & 2.78 & 0.54 \\
\hline Row-vector (sum) & $\mathbf{1 0 . 0 0}$ & 9.00 & 4.67 & $\mathbf{1 . 7 8}$ & 5.14 & 1.00 \\
\hline Consistency evaluation & \multicolumn{6}{|c|}{$\lambda_{\max }=4.086, I_{C}=0.028, I_{C R}=0.031$} \\
\hline
\end{tabular}


Table 13: Local priorities of the fourth level elements by "Subjective evaluation of taxation aspects" criterion

\begin{tabular}{|c|c|c|c|c|c|c|}
\hline \multirow{2}{*}{$\begin{array}{c}\text { Line numbers and names of } \\
\text { compared elements }\end{array}$} & \multicolumn{4}{|c|}{$\begin{array}{c}\text { Numbers } \\
\text { of compared elements }\end{array}$} & $\begin{array}{c}\text { Priority vector, } \\
\bar{u}_{\imath}\end{array}$ & $\begin{array}{c}\text { Local } \\
\text { priorities, } \mathrm{u}_{\mathrm{i}}\end{array}$ \\
\cline { 2 - 6 } & 1 & 2 & 3 & 4 & 0.34 & 0.06 \\
\hline 1. Government & 1.00 & 0.33 & 0.20 & 0.20 & 0.14 \\
\hline 2. Controlling bodies & 3.00 & 1.00 & 0.50 & 0.20 & 0.74 & 0.14 \\
\hline 3. Large taxpayers & 5.00 & 2.00 & 1.00 & 0.33 & 1.35 & 0.25 \\
\hline 4. Small taxpayers & 5.00 & 5.00 & 3.00 & 1 & 2.94 & 0.55 \\
\hline Row-vector (sum) & $\mathbf{1 4 . 0 0}$ & $\mathbf{8 . 3 3}$ & $\mathbf{4 . 7 0}$ & $\mathbf{1 . 7 3}$ & $\mathbf{5 . 3 7}$ & 1.00 \\
\hline Consistency evaluation & \multicolumn{6}{|c|}{$\lambda_{\max }=4.163, I_{C}=0.054, I_{C R}=0.06$} \\
\hline
\end{tabular}

Table 14: Local priorities of the fourth level elements by "Trust in government and taxation system" criterion

\begin{tabular}{|c|c|c|c|c|c|c|}
\hline \multirow{2}{*}{$\begin{array}{l}\text { Line numbers and names of } \\
\text { compared elements }\end{array}$} & \multicolumn{4}{|c|}{$\begin{array}{c}\text { Numbers } \\
\text { of compared elements }\end{array}$} & \multirow{2}{*}{$\begin{array}{l}\text { Priority vector, } \\
\qquad \bar{u}_{\imath}\end{array}$} & \multirow{2}{*}{$\begin{array}{c}\text { Local } \\
\text { priorities, } \mathrm{u}\end{array}$} \\
\hline & 1 & 2 & 3 & 4 & & \\
\hline 1. Government & 1.00 & 1.00 & 5.00 & 7.00 & 2.43 & 0.44 \\
\hline 2. Controlling bodies & 1.00 & 1.00 & 5.00 & 5.00 & 2.24 & 0.40 \\
\hline 3. Large taxpayers & 0.20 & 0.20 & 1.00 & 1.00 & 0.45 & 0.08 \\
\hline 4. Small taxpayers & 0.14 & 0.20 & 1.00 & 1 & 0.41 & 0.07 \\
\hline Row-vector (sum) & 2.34 & 2.40 & 12.00 & 14.00 & 5.53 & 1.00 \\
\hline Consistency evaluation & & & $\max =4$. & $14, I_{C}=$ & $0048, I_{C R}=0.00$ & \\
\hline
\end{tabular}

Table 15: Local priorities of the fourth level elements by "Emotional and volitional robustness of taxation subject" criterion

\begin{tabular}{|c|c|c|c|c|c|c|}
\hline \multirow{2}{*}{$\begin{array}{l}\text { Line numbers and names of } \\
\text { compared elements }\end{array}$} & \multicolumn{4}{|c|}{$\begin{array}{c}\text { Numbers } \\
\text { of compared elements }\end{array}$} & \multirow{2}{*}{$\begin{array}{c}\text { Priority vector, } \\
\overline{u_{\imath}}\end{array}$} & \multirow{2}{*}{$\begin{array}{c}\text { Local } \\
\text { priorities, } \mathrm{u}\end{array}$} \\
\hline & 1 & 2 & 3 & 4 & & \\
\hline 1. Government & 1.00 & 4.00 & 5.00 & 5.00 & 3.16 & 0.58 \\
\hline 2. Controlling bodies & 0.25 & 1.00 & 1.00 & 5.00 & 1.06 & 0.19 \\
\hline 3. Large taxpayers & 0.20 & 1.00 & 1.00 & 3.00 & 0.88 & 0.16 \\
\hline 4. Small taxpayers & 0.20 & 0.20 & 0.33 & 1 & 0.34 & 0.06 \\
\hline Row-vector (sum) & 1.65 & 6.20 & 7.33 & 14.00 & 5.44 & 1.00 \\
\hline Consistency evaluation & \multicolumn{6}{|c|}{$\lambda_{\max }=4.22, I_{C}=0.075, I_{C R}=0.083$} \\
\hline
\end{tabular}

Table 16: Local priorities of the fourth level elements by "Rate of adaptation to new conditions of activity" criterion

\begin{tabular}{|c|c|c|c|c|c|c|}
\hline \multirow{2}{*}{$\begin{array}{c}\text { Line numbers and names of } \\
\text { compared elements }\end{array}$} & \multicolumn{4}{|c|}{$\begin{array}{c}\text { Numbers } \\
\text { of compared elements }\end{array}$} & $\begin{array}{c}\text { Priority vector, } \\
\bar{u}_{\imath}\end{array}$ & $\begin{array}{c}\text { Local } \\
\text { priorities, } \mathrm{u}_{\mathrm{i}}\end{array}$ \\
\cline { 2 - 7 } & 1 & 2 & 3 & 4 & 0.67 & 0.13 \\
\hline 1. Government & 1.00 & 3.00 & 0.33 & 0.20 & 0.37 \\
\hline 2. Controlling bodies & 0.33 & 1.00 & 0.33 & 0.20 & 0.39 & 0.07 \\
\hline 3. Large taxpayers & 3.00 & 3.00 & 1.00 & 0.33 & 1.32 & 0.25 \\
\hline 4. Small taxpayers & 5.00 & 5.00 & 3.00 & 1 & 2.94 & 0.55 \\
\hline Row-vector (sum) & $\mathbf{9 . 3 3}$ & $\mathbf{1 2 . 0 0}$ & $\mathbf{4 . 6 7}$ & $\mathbf{1 . 7 3}$ & $\mathbf{5 . 3 1}$ & 1.00 \\
\hline Consistency evaluation & \multicolumn{7}{|c|}{$\lambda_{\max }=4.162, I_{C}=0.054, I_{C R}=0.06$} \\
\hline
\end{tabular}


Table 17: Local priorities of the fourth level elements by "Individual readiness to make decisions and take measures in terms of taxation" criterion

\begin{tabular}{|c|c|c|c|c|c|c|}
\hline \multirow{3}{*}{$\begin{array}{l}\text { Line numbers and names of } \\
\text { compared elements }\end{array}$} & \\
\hline & \multicolumn{4}{|c|}{$\begin{array}{c}\text { Numbers } \\
\text { of compared elements }\end{array}$} & \multirow{2}{*}{$\begin{array}{l}\text { Priority vector, } \\
\qquad \bar{u}_{\imath}\end{array}$} & \multirow{2}{*}{$\begin{array}{l}\text { Local } \\
\text { priorities, } \mathrm{u}_{\mathrm{i}}\end{array}$} \\
\hline & 1 & 2 & 3 & 4 & & \\
\hline 1. Government & 1.00 & 3.00 & 3.00 & 0.33 & 1.32 & 0.27 \\
\hline 2. Controlling bodies & 0.33 & 1.00 & 0.50 & 0.20 & 0.43 & 0.09 \\
\hline 3. Large taxpayers & 0.33 & 2.00 & 1.00 & 0.50 & 0.76 & 0.16 \\
\hline 4. Small taxpayers & 3.00 & 5.00 & 2.00 & 1 & 2.34 & 0.48 \\
\hline Row-vector (sum) & 1.00 & 3.00 & 3.00 & 0.33 & 4.84 & 1.00 \\
\hline Consistency evaluation & \multicolumn{6}{|c|}{$\lambda_{\max }=4.24, I_{C}=0.08, I_{C R}=0.089$} \\
\hline
\end{tabular}

Table 18: Local priorities of the fourth level elements by "Participation in or support of public initiatives in terms of taxation" criterion

\begin{tabular}{|c|c|c|c|c|c|c|}
\hline \multirow{3}{*}{$\begin{array}{l}\text { Line numbers and names of } \\
\text { compared elements }\end{array}$} & \\
\hline & \multicolumn{4}{|c|}{$\begin{array}{c}\text { Numbers } \\
\text { of compared elements }\end{array}$} & \multirow{2}{*}{$\begin{array}{l}\text { Priority vector, } \\
\bar{u}_{\iota}\end{array}$} & \multirow{2}{*}{$\begin{array}{c}\text { Local } \\
\text { priorities, u }\end{array}$} \\
\hline & 1 & 2 & 3 & 4 & & \\
\hline 1. Government & 1.00 & 3.00 & 0.33 & 0.20 & 0.67 & 0.13 \\
\hline 2. Controlling bodies & 0.33 & 1.00 & 0.20 & 0.20 & 0.34 & 0.06 \\
\hline 3. Large taxpayers & 3.00 & 5.00 & 1.00 & 2.00 & 2.34 & 0.45 \\
\hline 4. Small taxpayers & 5.00 & 5.00 & 0.50 & 1 & 1.88 & 0.36 \\
\hline Row-vector (sum) & 9.33 & 14.00 & 2.03 & 3.40 & 5.23 & 1.00 \\
\hline Consistency evaluation & \multicolumn{6}{|c|}{$\lambda_{\max }=4.23, I_{C}=0.078, I_{C R}=0.087$} \\
\hline
\end{tabular}

Table 19: Local priorities of the fourth level elements by "Socio-economic role in terms of taxation" criterion

\begin{tabular}{|c|c|c|c|c|c|c|}
\hline \multirow{2}{*}{$\begin{array}{c}\text { Line numbers and names of } \\
\text { compared elements }\end{array}$} & \multicolumn{4}{|c|}{$\begin{array}{c}\text { Numbers } \\
\text { of compared elements }\end{array}$} & \multirow{2}{*}{$\begin{array}{c}\text { Local } \\
\bar{u}_{\imath}\end{array}$} & priorities, $\mathrm{u}_{\mathrm{i}}$ \\
\cline { 2 - 6 } & 1 & 2 & 3 & 4 & 2.43 & 0.47 \\
\hline 1. Government & 1.00 & 1.00 & 5.00 & 7.00 & 2.73 & 0.33 \\
\hline 2. Controlling bodies & 1.00 & 1.00 & 3.00 & 3.00 & 1.73 & 0.15 \\
\hline 3. Large taxpayers & 0.20 & 0.33 & 1.00 & 5.00 & 0.76 & 0.06 \\
\hline 4. Small taxpayers & 0.14 & 0.33 & 0.20 & 1 & 0.31 & 1.00 \\
\hline Row-vector (sum) & $\mathbf{2 . 3 4}$ & $\mathbf{2 . 6 7}$ & $\mathbf{9 . 2 0}$ & $\mathbf{1 6 . 0 0}$ & $\mathbf{5 . 2 4}$ & \\
\hline Consistency evaluation & \multicolumn{8}{|c|}{$\lambda_{\max }=4.265, I_{C}=0.08, I_{C R}=0.09$} & \\
\hline
\end{tabular}

Table 20: Local priorities of the fourth level elements by "Behavior patterns of surrounding subjects of taxation" criterion

\begin{tabular}{|c|c|c|c|c|c|c|}
\hline \multirow{2}{*}{$\begin{array}{c}\text { Line numbers and names of } \\
\text { compared elements }\end{array}$} & \multicolumn{4}{|c|}{$\begin{array}{c}\text { Numbers } \\
\text { of compared elements }\end{array}$} & \multirow{2}{*}{$\begin{array}{c}\text { Priority vector, } \\
\bar{u}_{\imath}\end{array}$} & $\begin{array}{c}\text { Local } \\
\text { priorities, } \mathrm{u}_{\mathrm{i}}\end{array}$ \\
\cline { 2 - 6 } & 1 & 2 & 3 & 4 & 0.39 & 0.07 \\
\hline 1. Government & 1.00 & 0.33 & 0.33 & 0.20 & 0.39 \\
\hline 2. Controlling bodies & 3.00 & 1.00 & 0.33 & 0.20 & 0.67 & 0.13 \\
\hline 3. Large taxpayers & 3.00 & 3.00 & 1.00 & 0.33 & 1.32 & 0.25 \\
\hline 4. Small taxpayers & 5.00 & 5.00 & 3.00 & 1 & 2.94 & 0.55 \\
\hline Row-vector (sum) & 1.00 & 0.33 & 0.33 & 0.20 & $\mathbf{5 . 3 1}$ & 1.00 \\
\hline Consistency evaluation & \multicolumn{7}{|c|}{$\lambda_{\max }=4.162, I_{C}=0.054, I_{C R}=0.06$} \\
\hline
\end{tabular}


Table 21: Local priorities of the fourth level elements by "Tax behavior alternatives availability and risks" criterion

\begin{tabular}{|c|c|c|c|c|c|c|}
\hline \multirow{2}{*}{$\begin{array}{c}\text { Line numbers and names of } \\
\text { compared elements }\end{array}$} & \multicolumn{4}{|c|}{$\begin{array}{c}\text { Numbers } \\
\text { of compared elements }\end{array}$} & $\begin{array}{c}\text { Priority vector, } \\
\overline{u_{\imath}}\end{array}$ & $\begin{array}{c}\text { Local } \\
\text { priorities, } \mathrm{u}_{\mathrm{i}}\end{array}$ \\
\cline { 2 - 6 } & 1 & 2 & 3 & 4 & 0.53 & 0.10 \\
\hline 1. Government & 1.00 & 2.00 & 0.20 & 0.20 & 0.38 & 0.07 \\
\hline 2. Controlling bodies & 0.50 & 1.00 & 0.20 & 0.20 & 0.38 & 0.31 \\
\hline 3. Large taxpayers & 5.00 & 5.00 & 1.00 & 0.33 & 1.70 & 0.53 \\
\hline 4. Small taxpayers & 5.00 & 5.00 & 3.00 & 1 & 2.94 & 1.00 \\
\hline Row-vector (sum) & $\mathbf{1 1 . 5 0}$ & $\mathbf{1 3 . 0 0}$ & $\mathbf{4 . 4 0}$ & $\mathbf{1 . 7 3}$ & $\mathbf{5 . 5 5}$ & \\
\hline Consistency evaluation & \multicolumn{8}{|c|}{$\lambda_{\max }=4.249, I_{C}=0.08, I_{C R}=0.09$} & \\
\hline
\end{tabular}

\section{References}

[1] A. Abdul-Razak, C. J. Adafula, "Evaluating taxpayers' attitude and its influence on tax compliance decisions in Tamale, Ghana,"Journal of Accounting and Taxation, vol. 5(3), pp. 48-57, 2013.

[2] Z. Berhane, "The Influence of Tax Education on Tax Compliance Attitude," LAP LAMBERT Academic Publishing, p. 196, August 14, 2012.

[3] Z. Bidin, M. Marimuthu, C. Derashid, K. M. Idris, N. Ahmad, "Determinants of attitude toward proposed good and services tax among business communities in Malaysia," International Review of Management and Marketing, vol. 6(8S), pp. 193-197, 2016.

[4] C. Castelfranchi, R. Falcone, "Trust Theory: A Socio-cognitive and Computational Model," West Sussex: John Wiley \& Sons Ltd. p. 386, 2010.

[5] I. Daugule, A. Kapenieks,"Knowledge flow analysis: the quantitative method for knowledge stickiness analysis in online course," Periodicals of Engineering and Natural Sciences (PEN), vol. 7.1, pp. 165$171,2019$.

[6] K. Devos, "Factors influencing individual taxpayer compliance behavior," Springer Science \& Business Media, p. 342, 2013.

[7] EU Commission. Directorate-General for Economic and Financial Affairs Directorate-General for Taxation and Customs Union. Tax Reforms in EU Member States : Tax policy challenges for economic growth and fiscal sustainability : European Communities, Report (No. 8), p.132, 2015.

[8] E. N. Fadzilah, R. M. Mustafa, N. K. Putri, "The Effect of Tax Understanding, Tax Payness Consciousness, Quality of Tax Service, and Tax Sanctions on Compulsory Tax of SMEs In Banyumas," Acta Universitatis Danubius. Economica, vol. 13 (4), pp. 28-38, 2017.

[9] U. Gergerlioğlu, R. W. McGee, "University Students' Attitudes Towards Tax Consciousness: A Case Study of the Faculty of Economics at Istanbul University," vol. 5. 10, pp. 383-407, 2017.

[10] O. Gursoy, M. H. Sharif, "Parallel computing for artificial neural network training," Periodicals of Engineering and Natural Sciences (PEN), vol. 6(1), pp. 1-10, 2018.

[11] N. Hashimzade, G. D. Myles, F. Page, M. D. Rablen, "Social networks and occupational choice: The endogenous formation of attitudes and beliefs about tax compliance,"Journal of Economic Psychology, vol. 40, pp. 134-146, 2014.

[12] R. Hastuti, "Tax Awareness and Tax Education: A Perception of Potential Taxpayers,"International Journal of Business, Economics and Law, vol. 5(1), pp. 83-91, 2014.

[13] M. Hodzic, "Uncertainty balance principle," Periodicals of Engineering and Natural Sciences (PEN), vol.4(2), pp. 17-32, 2016.

[14] J. S. Kim, "Analysis of the Tax Consciousness of a Taxpayer and a Tax Agent," The Journal of the Korea Contents Association, vol. 8(10), pp. 142-150, 2008.

[15] H. Kucherova, "Methods of Evaluating Taxpayers' Tax Consciousness. Transformations in Contemporary Society: Economic Aspects", Monograph. Opole: The Academy of Management and Administration in Opole: 2017; ISBN 987-83-62683-96-3; p. 243-250.

[16] H. Y. Kucherova, P. V. Komazov, "Substantiation of tax consciousness model for subjects of taxation on the basis of reflexive interaction,"Středoevropský věstnik pro vědu a výzkum, vol. 3 (16), pp. 9-19, 2015. 
[17] H. Kucherova, L. Serhieieva, O. Bilska, "Assessment of tax subjects' interaction under uncertainty of socio-economic processes," SHS Web of Conferences, EDP Sciences, vol. 65, p. 01002. DOI : https://doi.org/10.1051/shsconf/20196501002

[18] C. J. B. L. Kun, "Empirical Study on Enterprise's Tax Compliance Consciousness and Its Influencing Factors," Journal of Central University of Finance \& Economics, vol. 7, p. 004, 2010.

[19] S. Liang, "Research on Tax Compliance Strategy Based on Evolutionary Game Theory," Journal of Industrial Technological Economics, vol. 2, p. 026, 2011.

[20] Y. LIU, Y YI, "A Research on Taxpayer's Consciousness in Van Raaij Model," Finance \& Trade Economics, vol. 7, p. 006, 2005.

[21] S. Muehlbacher, E. Kirchler, H. Schwarzenberger, "Voluntary versus Enforced Tax Compliance: Empirical Evidence for the "Slippery Slope" Framework," European Journal of Law and Economics, vol. 32, pp. 89-97, 2011.

[22] S. Muehlbacher, C. Kogler, E. Kirchler, "An Empirical Testing of the Slippery Slope Framework: The Role of Trust and Power in Explaining Tax Compliance," Paper presented at the Shadow Economy, Tax Evasion and Money Laundering Conference, University of Vienna Working Paper, Muenster, Germany, July 28-31, 2011.

[23] D. Nur Pertiwi, "The Influence of Tax Consciousness, Service Tax Authorities and Tax Sanctions on Tax Compliance (Survey On Individual Taxpayer Conducting Business Operations and Professional Service in Jakarta) [Thesis]. Jakarta: State Islamic University Syarif Hidayatullah. 2013.

[24] I. K. Nurlis, "The Effect of Taxpayer Consciousness, Knowledge, Tax Penalties and Tax Authorities Services on the Tax Compliance: (Survey on the Individual Taxpayer at Jabodetabek \& Bandung), " Research Journal of Finance and Accounting, vol.6, No: 2, pp. 104-112, 2015.

[25] OECD. Building Tax Culture, Compliance and Citizenship. OECD Publishing, Paris, 2015.

[26] A. Prinz, S. Muehlbacher, E. Kirchler, "The slippery slope framework on tax compliance: An attempt to formalization," Journal of Economic Psychology, vol. 40, pp. 20-34, 2014.

[27] T.L. Saaty, "The Analytic Hierarchy Process," McGraw-Hill, New York, 1980.

[28] Tax Transparency : Seizing the Initiative, London : Ernst\&Young LLP, p.49, 2013. Retrieved from: https://www.ey.com/Publication/vwLUAssets/Tax_Transparency___Seizing_the_initiative/\% 24FILE/EY_Tax_Transparency.pdf

[29] E. Teyyare, E. Kumbaşl1, "The Role of Department of Public Finance Training In The Development Tax Consciousness And Morale", Journal of Institute of Social Sciences, vol. 16.16.4, pp. 1-29, 2016. DOI: https://doi.org/10.11616/basbed.vi.455401

[30] S. Ulubeyli, A. Kazaz, V. Arslan, "A structured selection process for small and medium enterprises in construction industry: case of international projects," Periodicals of Engineering and Natural Sciences (PEN), vol. 5(3). pp. 263-270, 2017.

[31] K. Valtins, N. Muracova, "Virtual mobility for students, going from distance learning to live participation," Periodicals of Engineering and Natural Sciences (PEN), vol. 7.1, pp. 222-227, 2019.

[32] W. F. van Raaij, "Tax Behavior: Compliance and Evasion. In Understanding Consumer Financial Behavior," Palgrave Macmillan, New York, pp. 103-111, 2016.

[33] T. O. Weber, J. Fooken, B. Herrmann, "Behavioural economics and taxation," Directorate General Taxation and Customs Union, European Commission, vol. 41, 2014.

[34] J. Larson-Hall, "A guide to doing statistics in second language research using SPSS and R", Routledge, p. $528,2015$.

[35] M. Yardımcıoğlu, Y. Akpınar, Y. Günay, "Tax literacy and tax awareness: hero research," Journal of Kahramanmaras Sutcu Imam University, Faculty of Economics and Administrative Sciences, vol. 4 (2), pp. 95-122, 10 March, 2015. Retrieved from: http://iibfdergisi.ksu.edu.tr/download/article-file/107719

[36] V. Zagorskis, A. Kapenieks, A. Gorbunovs, "Emotions identification utilizing periodic handwriting on mobile surfaces,"Periodicals of Engineering and Natural Sciences (PEN), vol. 7.1, pp. 228-237, 2019. 


\section{BIBLIOGRAPHY OF AUTHORS}

Kucherova Hanna received the Doctor degree in Economics from the Classic Private University,
Zaporizhzhia, Ukraine in 2017 and is currently a lecturer with the same institution. Her publications
include more than 100 papers published in national or international scientific journals or presented at
international conferences. Her research interests include, among others, tax consciousness, tax behavior,
assessment interaction between taxpayers, controlling bodies and public authorities, modeling the impact
of taxation on the development of small enterprises.
$\begin{aligned} & \text { Pokataieva Olga, Doctor of Economics (2010), Doctor of the Science of Law (2011), now - professor and } \\ & \text { First Deputy Rector of the Classic Private University, Zaporizhzhia, Ukraine. Her publications include } \\ & \text { more than } 200 \text { papers published in national or international scientific journals or presented at international } \\ & \text { conferences. Her domains of interest are, among others, tax law, national economy, state policy, } \\ & \text { regulatory policy, fiscal policy of the state social and economic development of the state. } \\ & \text { Bilska Olha received the Doctor degree in Economics from the Classic Private University, Zaporizhzhia, } \\ & \text { Ukraine in } 2018 \text { and is currently a lecturer with the same institution. Her publications include more than } \\ & 60 \text { papers published in national or international scientific journals or presented at international } \\ & \text { conferences. Her research interests include, among others, national economy, socialisation of economy, } \\ & \text { tax consciousness, assessment interaction between taxpayers, controlling bodies and public authorities. }\end{aligned}$

